[WASHINGTON] A number of non-US research staff hired by American universities are stranded without visas to enter the country following political stalemate over quotas for overseas-born professionals.

The visa problem is holding up temporary faculty appointments at a number of institutions, according to Sang Han, who tracks immigration issues for the Association of American Universities (AAU).

"At least three department heads are tearing their hair out" because non-US faculty members who were supposed to begin teaching classes in September will not arrive in time, says Richard Lariviere, vice-president of international programs at the University of Texas.

Visa applications in the ' $\mathrm{H}-1 \mathrm{~B}$ ' category - which includes computer programmers, physical therapists, and university jobs ranging from visiting professors to research associates - have been frozen since May, when the annual quota of 65,000 visas was filled.

A bill proposed by Congressman Lamar Smith (Republican, Texas) would add another 20,000 slots for this fiscal year, which ends on 30 September. But the bill was withdrawn last week, under threat of a presidential veto. The earliest Congress can take up the matter now is 9 September, when the House of Representatives returns from a month-long recess.

The controversy has its roots in the politics of the labour market for computer programmers and systems analysts, rather than academic scientists. The US software industry has lobbied strenuously for an increase in the number of $\mathrm{H}-1 \mathrm{~B}$ visas, claiming that a shortage of native-born workers forces it to hire programmers from India and other countries.

But opponents of an $\mathrm{H}-1 \mathrm{~B}$ increase including some labour unions - say there is no domestic labour shortage. They say Silicon Valley companies are simply trying to hold down wages by hiring lower-paid staff from overseas.

The White House is torn between its desire to serve the politically powerful software industry, and its desire to side with workers' organizations. To become law, Smith's bill is likely to need stronger protection for US workers.

Universities are caught in the crossfire. They filed only two per cent of the 400,000 applications for $\mathrm{H}-1 \mathrm{~B}$ visas last year (40 per cent of the applications to the Department of Labor were for programmers and 25 per cent for physical therapists).

Lariviere says the academic community is more discriminating than the software industry. "These [faculty members] are really very carefully targeted individuals," he says. "Our mandate is to find the best per- son," unlike the software industry which, he claims, fills "job shops" with programmers holding temporary visas.

Smith's proposed legislation, a version of which has already passed the Senate, would raise the $\mathrm{H}-1 \mathrm{~B}$ quota to 95,000 next year, 105,000 in 2000, and 115,000 in 2001 and 2002 , before dropping to 65,000 again in 2003.

But, even if these increases are approved, Lariviere worries that they will only delay the inevitable, and that the $\mathrm{H}-1 \mathrm{~B}$ slots will still run out before the end of the year. "I suspect all we've done [with the bill] is move back slightly the date when the cap will be hit."

\section{Geneticists told to debate with politicians}

[BEIJING] Geneticists throughout the world should engage more deeply in discussion with their governments on the implications of their work, and not stay aloof from such debates, one of the leading figures in the US Human Genome Project told an international meeting this week.

Maynard Olson, a professor of genetics at the University of Washington in Seattle, made his appeal in a plenary address to the Eighteenth International Congress of Genetics, which is being held in Beijing under the sponsorship of the Chinese Academy of Sciences and the Genetics Society of China.

The meeting is the third such congress to be held in Asia, after Tokyo in 1968 and New Delhi in 1983. The decision to hold it in China, which was made at the last congress, in Birmingham, United Kingdom, in 1993, has been controversial ever since China drafted a 'eugenics' law (see Nature 372, 123 ; 1994).

This law, which came into force in 1995, requires physicians to recommend couples to postpone marriage if one partner is found to have a series contagious or mental disease. Those diagnosed with a "genetic disease of a serious nature" are asked to take unspecified long-term contraceptive measures or to be sterilized.

After the decision to hold the meeting in Beijing had been confirmed, three national genetics associations - those in the United Kingdom, Argentina and the Netherlands withdrew in protest from the International Genetics Federation (IGF), under whose auspices the regular international congresses are held, advocating a boycott by their members.

Other associations argued in favour of attending the meeting, and rejected the call for a boycott. But several did so only after they had been promised that the programme would include an open debate
In addition, universities fear that the software industry will quickly swallow up any new slots, steadily reducing the number of visas left for universities. Extra programmers are being recruited to help solve the 'millennium bug' problem.

Applications for $\mathrm{H}-1 \mathrm{~B}$ visas are 'firstcome, first-served,' with no quotas for any category of worker. The ceiling is reached earlier every year. In 1997 all 65,000 slots were taken by July, but this year they lasted only until May.

Han of the AAU says that, if nothing changes, next year's allocation of visas may all be gone by January.

Tony Reichhardt with Chinese geneticists about the Maternal and Infant Health Care law and the potential dangers of its rigid application.

Although the local organizing committee in Beijing subsequently agreed to a request from the executive committee of the IGF to include a symposium on eugenics, this has been broadened into a general session on the ethical, legal and social implications of genetics research.

However, it will be followed by an evening workshop on the science and ethics of eugenics, chaired by Anthony Griffiths, professor of botany at the University of British Columbia, Canada, the secretary of the IGF, and Renzhong Qiu of the Chinese Academy of Social Science.

The eugenics issue was not referred to in the opening ceremonies of the congress, which concentrated on its main theme, "Genetics - Better life for All”. The president of the congress, veteran Chinese geneticist C. C. Tan, emphasized how genetics can improve the quality of life, for example by helping to increase food production.

"With the world's population estimated to increase from 5.9 billion to more than 7 billion in 100 years' time, we face the question of whether the human species can sustain itself on Earth," said Tan. "Food production has to keep up with population growth, and international cooperation is clearly indispensable in developing new plant breeding skills."

Discussing the international implications of human genome analysis, Olson argued that it was wrong for geneticists or governments to spend too much energy on the relatively short-term issue of intellectual property rights over genetic material. "The issue that all countries should focus on is the development of their local scientific capacity," he said.

David Dickson 